\title{
Adsorption of Heavy Metal Ions from Aqueous Solutions onto Rice Husk Ash Low Cost Adsorbent
}

\author{
El-Said AG ${ }^{1}$, Badawy NA' ${ }^{1}$ and Garamon SE $^{2^{*}}$ \\ ${ }^{1}$ Chemistry Department. Faculty of Science, Al-Azhar University (Girls), Nasr City, Cairo, Egypt \\ ${ }^{2}$ Chemistry Department. Faculty of Science and Arts, Aljouf University, Kingdom of Saudi Arabia
}

\begin{abstract}
In the present study, adsorption of $\mathrm{Zn}$ (II), Cd (II) and $\mathrm{Hg}$ (II) ions on rice husk ash (RHA) has been investigated in single, binary and tertiary systems. Batch experiments were also carried out for mono- and multi-component systems with varying metal ions concentrations $(\mathrm{mg} / \mathrm{l})$ to investigate the competitive adsorption characteristics. Rice husk ash (RHA) has been studied for their adsorption properties pertaining to mono component solutions of metal ions. However, to treat waste water with new materials, their performance needs to be ascertained in multi component system. The scanning electron micrographs (SEM) of rice husk ash surfaces before and after the adsorbent was equilibrated with the metal ions solution, clearly establishes the presence of the metal ions and some surface modifications can be observed on the rice husk ash particles adsorption with (i) surface chemistry of the pellets on the surface of rice husk ash and (ii) inside layers of the rice husk ash. Applicability of the isotherm models namely Freundlish and Langmuir to predict the equilibrium uptake of $\mathrm{Zn}(\mathrm{II}), \mathrm{Cd}(\mathrm{II})$ and $\mathrm{Hg}(\mathrm{II})$ in mono, binary and tertiary systems have also been tested.
\end{abstract}

Keywords: Metal ions; Adsorption behavior; Competitive sorption; Rice husk ash

\section{Introduction}

The pollution of water resources due to the indiscriminate disposal of heavy metals has been causing world wide concern for the last few decades. It is well known that some metals can have toxic or harmful effects on many forms of life. Among the most toxic metals are $\mathrm{Cr}$, $\mathrm{Cu}, \mathrm{Pb}, \mathrm{Zn}$ and $\mathrm{Hg}$, which is one of the hazardous priority substances in the list of pollutants contained in the water Framework directive. (Directive 2000/60/Ec) [1]. Over the past few years, new and/or tighter regulations coupled with increased enforcement concerning waste water discharges have been established in many countries. This challenge has prompted intensive research in new advanced treatment technologies, some of which are currently making their way to full-scale installations. In the literature on this field, several processes of treatment have been proposed to remove heavy metals from aqueous streams, coagulation, chemical precipitation, evaporation, electrolysis, adsorption, and reverse osmosis. However, these conventional technologies may be inadequate and expensive and usually cause secondary problems. Therefore among these processes, adsorption is probably the most attractive because its application is simple as well as competitive and efficient [2]. Yet, the cost of the adsorbent and its regeneration may be a limiting factor. At present, there is a growing interest not only in using low-cost materials with adsorptive purposes but from a different scientific point of view, there is also growing concern about the reuse and/or recycling of waste and other such materials [3]. Several recent publications utilized different inexpensive and locally abundantly available adsorbent like rice husk and its ash [4].

Rice husk is used as a fuel by a number of industries to produce steam, thus, conserving both energy and resources. During the burning of rice husk, the residue ash, called rice husk ash (RHA) is collected from the dust collection device attached up stream to the stacks of rice huskfired boilers and furnaces. RHA has good adsorptive properties, and has been used previously for the adsorptive removal of metal ions [3].

Heavy metals have cumulative effects and tend to accumulate in the living organisms causing various diseases and disorders. In humans zinc [Zn (II)] is found in over 20 metalloenzymes, including several that are involved in nucleic acid metabolism. Excess ingestion of $\mathrm{Zn}$ (II) may result in acute gastrointestinal disturbances accompanied with nauseas. Instances of acute toxicity have occurred from ingestion of fruit juices that were stored galvanized (Zinc plated) steel containers [5]. Cadmium $[\mathrm{Cd}$ (II)] is a non-essential and non-biodegradable metal which slowly accumulates in the human body, usually from food-chain. The body slowly releases adsorbed Cd (II) which has a biological half-life of more than 10 years. As a consequence, the Cd (II) content of the kidney increases throughout life. Ingested Cd (II) is transported to the other organs by the blood, where it is bound by glutathione and hemoglobin in the red blood cells [5].

Mercury [Hg (II)] is a previous contaminant that is highly toxic and is readily accumulated by organisms [6,7]. The major effects of mercury poisoning are neurological and renal disturbance as well as impairment of pulmonary function [8,9]. Although much research information is available on the single metal biosorption [10,11], relatively less attention has been paid to the biosorption of multi-metal-ion system. In multi-component systems, sorption of heavy metal ions depend onto only on the specific surface properties, of the biomass and on the physicochemical parameters of the solution, say, temperature, $\mathrm{pH}$, initial metal-ion concentration and biomass concentration, but also on features of those components, as well as the number of those different

*Corresponding author: Garamon SE, Chemistry Department. Faculty of Science and Arts, Aljouf University, Kingdom of Saudi Arabia, Tel: +966538953473; E-mail: salwachem@yahoo.com

Received January 02, 2018; Accepted January 11, 2018; Published January 16 2018

Citation: El-Said AG, Badawy NA, Garamon SE (2018) Adsorption of Heavy Metal Ions from Aqueous Solutions onto Rice Husk Ash Low Cost Adsorbent J Environ Anal Toxicol 7: 543. doi: 10.4172/2161-0525.1000543

Copyright: ( $) 2018$ El-Said AG, et al. This is an open-access article distributed under the terms of the Creative Commons Attribution License, which permits unrestricted use, distribution, and reproduction in any medium, provided the original author and source are credited. 
Citation: El-Said AG, Badawy NA, Garamon SE (2018) Adsorption of Heavy Metal lons from Aqueous Solutions onto Rice Husk Ash Low Cost Adsorbent J Environ Anal Toxicol 7: 543. doi: 10.4172/2161-0525.1000543

Page 2 of 5

metal ions competing for binding sites, metal combination, levels of metal concentration, residence time and test criteria [12].

The purpose of this study has been to investigate the adsorption characteristics of three heavy metals $\mathrm{Zn}$ (II), Cd(II) and (Hg)(II), onto rice husk ash in single, binary and tertiary systems. The main objectives of these competitive sorption studies were:

[a] to assess the efficacy of rice husk ash (RHA) for removal of $\mathrm{Zn}$ (II), Cd (II) and (Hg) (II) in multimetal adsorption systems.

[b] To provide a quantitative estimation of adsorption capacity of (RHA) in competitive sorption system.

The Langmuir and Frendlich isotherms were used to describe the equilibrium uptake of $\mathrm{Zn}$ (II), Cd (II) and $\mathrm{Hg}$ (II) in mono-component, binary and tertiary system.

\section{Experimental}

\section{Adsorbent and its characterization}

Rice husk ash (RHA) is a solid obtained from rice processing mill after burning of rice husk. The physicochemical characterization of rice husk ash (RHA) was performed using standard procedures. Table 1 shows the chemical composition of rice husk ash (RHA). To understand the morphology of the samples was studied by using (JEOLSEM-25) scanning electron microscope, Japan. Prior to examination, the samples were gold sputter coated and the scanning electron microscopic (SEM) micrograph was taken (Figure 1).

\section{Adsorbates}

All the chemicals used in the study were of analytical reagent (AR) grade and obtained from Merck (Germany). Stock solutions of $\mathrm{Zn}$ (II), $\mathrm{Cd}$ (II) and $\mathrm{Hg}$ (II) were made by dissolving exact amount of, $\mathrm{ZnSO}_{4}$, $\mathrm{CdSO}_{4}$ and $\mathrm{HgCl}_{2} 7 \mathrm{H}_{2} \mathrm{O} .8 \mathrm{H}_{2} \mathrm{O}$ with bidistilled water respectively. The range of concentration of metal components prepared from stock solution varied between 10 and $100 \mathrm{mg} / \mathrm{L}$. metal ions were analyzed with plasma optical emission mass spectrometer (POE MSIII) with merch 23 element multi element stander.

\section{Methodology}

\section{Mono-component adsorption of metal ions}

Batch mode adsorption studies of $\mathrm{Zn}$ (II), $\mathrm{Cd}(\mathrm{II})$ and (Hg)(II) were carried out at $30^{\circ} \mathrm{C}$ using $100 \mathrm{ml}$ of metal ion solution with concentration ranging between 10 to $100 \mathrm{mg} / \mathrm{l}$ and $10 \mathrm{~g} / \mathrm{l}$ of adsorbent and agitated

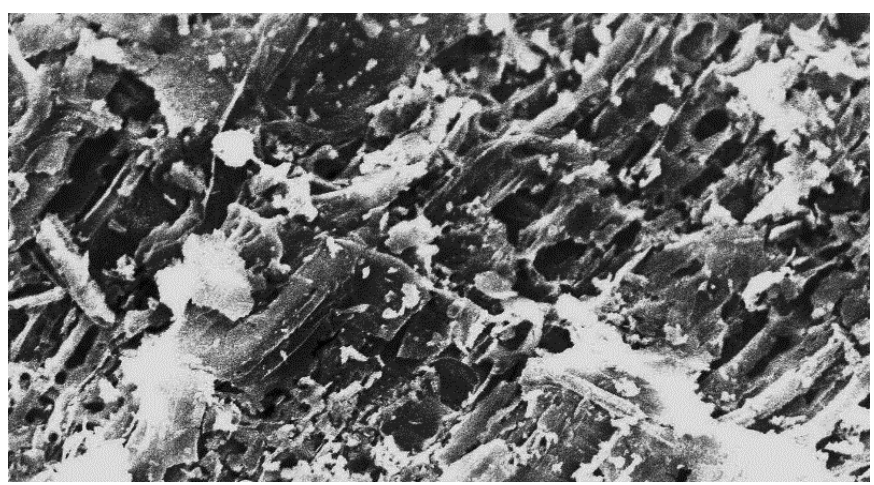

RHA + Metal ion

Figure 1: SEM micrographs of the rice husk ash indicated that the surface was highly irregular and porous in nature. using mechanical shaker at $120 \mathrm{rpm}$. After equilibrium adsorption the samples were withdrawn and separated. All the experiments were carried out initial at $\mathrm{pH}$ 6.0, (adjusted using diluted $\mathrm{HCl}$ or $\mathrm{NaOH}$ ), where the adsorption is significant. The final (residual) metal concentrations $\left(\mathrm{C}_{\mathrm{e}}\right)$ for different metal systems in test solution were analyzed, leading to the respective calculated values for adsorbent metal uptake. Metal uptake or surface loading, $\mathrm{q}_{\mathrm{e}}$ for each sorption system was calculated using the general definition [2].

$$
\mathrm{q}_{\mathrm{e}}(\mathrm{g} / \mathrm{g})=\frac{\mathrm{V}\left(\mathrm{C}_{\mathrm{i}}-\mathrm{C}_{\mathrm{e}}\right)}{\mathrm{W}}
$$

Where, $\mathrm{C}_{\mathrm{i}}$ is the initial metal concentration $\mathrm{mg} / \mathrm{l} \mathrm{Ce}$ in the equilibrium metal concentration $(\mathrm{mg} / \mathrm{l})$ in solution, $\mathrm{V}$ is volume $(\mathrm{L})$ and $\mathrm{w}$ is the mass of adsorbent $(\mathrm{g})$.

\section{Binary and tertiary adsorption metal ions}

Binary and tertiary component adsorption systems were prepared by solubilizing a combination of either $\mathrm{Zn}$ (II)- $\mathrm{Cd}$ (II) or $\mathrm{Cd}$ (II)- $\mathrm{Hg}$ (II) or $\mathrm{Hg}(\mathrm{II})-\mathrm{Zn}(\mathrm{II})$ or $\mathrm{Zn}(\mathrm{II})-\mathrm{Cd}(\mathrm{II})-\mathrm{Hg}(\mathrm{II})$ with presence of each metal $[\mathrm{Zn}(\mathrm{II}) / \mathrm{Cd}(\mathrm{II}) / \mathrm{Hg}(\mathrm{II})]$ with other metal/metals present in equal concentrations $(\mathrm{mg} / \mathrm{l})$. Binary and tertiary component adsorption of metal ions was conducted with the same operating conditions as for mono-component adsorption in terms of volume (100 ml), RHA weight $(1 \mathrm{~g}), \mathrm{pH} 6$, agitation time $(6 \mathrm{hr})$ and agitation rate $(120 \mathrm{rpm})$. Initial individual concentrations of three metal ions (in binary or tertiary system) ranged from 10 to $100 \mathrm{mg} / \mathrm{l}$. Obtained results were modeled using Longmuir and Freundlich equations.

\section{Results and Discussion}

\section{Mono component adsorption}

Results obtained for the adsorption was determined with respect

\begin{tabular}{|c|c|}
\hline \multicolumn{2}{|c|}{ Characteristic RHA } \\
\hline \multicolumn{2}{|c|}{ Proximate analysis } \\
\hline Moisture (\%) & 0.73 \\
\hline Ash (\%) & 88.0 \\
\hline Volatile matter (\%) & 5.37 \\
\hline Fixed carbon (\%) & 5.90 \\
\hline \multicolumn{2}{|c|}{ Chemical analysis of ash } \\
\hline Insoluble & 75.17 \\
\hline $\mathrm{SiO}_{2}(\%)$ & 2.60 \\
\hline $\mathrm{Fe}_{2} \mathrm{O}_{3}$ and $\mathrm{Al}_{2} \mathrm{O}_{3}(\%)$ & 3.38 \\
\hline $\mathrm{CaO}(\%)$ & 17.40 \\
\hline $\mathrm{MgO}(\%)$ & 0.96 \\
\hline Rest others & 0.49 \\
\hline Bulk density $\left(\mathrm{Kg} / \mathrm{m}^{3}\right)$ & 104.9 \\
\hline \multicolumn{2}{|c|}{ CHN analysis } \\
\hline $\mathrm{C}(\%)$ & 7.42 \\
\hline $\mathrm{H}(\%)$ & 0.06 \\
\hline $\mathrm{N}(\%)$ & 0.85 \\
\hline
\end{tabular}

Table 1: Characteristics of RHA

\begin{tabular}{|c|c|c|c|c|c|c|}
\hline \multirow{2}{*}{ Metal ion } & \multicolumn{3}{|c|}{ Langmuir model } & \multicolumn{3}{c|}{ Freundlich model } \\
\cline { 2 - 7 } & $\mathbf{Q}_{\mathbf{o}}(\mathbf{m g} / \mathbf{g})$ & $\mathbf{b}(\mathbf{l} / \mathbf{m g})$ & $\mathbf{r}^{\mathbf{2}}$ & $\mathbf{K}_{\mathbf{f}}$ & $\mathbf{1 / n}$ & $\mathbf{r}^{\mathbf{2}}$ \\
\hline $\mathrm{Zn}(\mathrm{II})$ & 9.588 & 0.096 & 0.981 & 1.056 & 0.592 & 0.982 \\
\hline $\mathrm{Cd}(\mathrm{II})$ & 6.579 & 0.078 & 0.967 & 0.787 & 0.503 & 0.999 \\
\hline $\mathrm{Hg}(\mathrm{II})$ & 4.000 & 0.074 & 0.977 & 0.600 & 0.416 & 0.996 \\
\hline
\end{tabular}

Table 2: Equilibrium models for adsorption isotherm of zinc, cadmium and mercury on to rice husk ash in mono component system. 
Citation: El-Said AG, Badawy NA, Garamon SE (2018) Adsorption of Heavy Metal lons from Aqueous Solutions onto Rice Husk Ash Low Cost Adsorbent J Environ Anal Toxicol 7: 543. doi: 10.4172/2161-0525.1000543

Page 3 of 5

\begin{tabular}{|c|c|c|c|c|c|c|c|}
\hline & \multirow[b]{2}{*}{ Metal ions } & \multicolumn{3}{|c|}{ Langmuir parameters } & \multicolumn{3}{|c|}{ Freundlish parameters } \\
\hline & & $\begin{array}{c}Q_{o} \\
(\mathrm{mg} / \mathrm{g})\end{array}$ & $1 / \mathrm{b}(\mathrm{l} / \mathrm{mg})$ & $\mathbf{r}^{2}$ & $K_{f}$ & $1 / n$ & $\mathbf{r}^{2}$ \\
\hline \multicolumn{8}{|c|}{ Binary Metal system } \\
\hline \multirow{2}{*}{$\mathrm{Zn}(\mathrm{II})+\mathrm{Cd}(\mathrm{II})$} & $\mathrm{Zn}(\mathrm{II})$ & 3.453 & 0.131 & 0.991 & 0.818 & 0.328 & 0.996 \\
\hline & $\mathrm{Cd}(\mathrm{II})$ & 2.092 & 0.194 & 0.993 & 0.648 & 0.262 & 0.965 \\
\hline \multirow{2}{*}{$\mathrm{Cd}(\mathrm{II})+\mathrm{Hg}(\mathrm{II})$} & $\mathrm{Cd}(\mathrm{II})$ & 2.463 & 0.106 & 0.984 & 0.620 & 0.296 & 0.986 \\
\hline & $\mathrm{Hg}(\mathrm{II})$ & 2.072 & 0.068 & 0.980 & 0.365 & 0.364 & 0.999 \\
\hline \multirow{2}{*}{$H g(I I)+Z n(I I)$} & $\mathrm{Hg}(\mathrm{II})$ & 2.206 & 0.090 & 0.972 & 0.563 & 0.277 & 0.991 \\
\hline & $\mathrm{Zn}(\mathrm{II})$ & 4.000 & 0.119 & 0.984 & 0.864 & 0.355 & 0.988 \\
\hline \multicolumn{8}{|c|}{ Tertiary Metal system } \\
\hline \multirow{3}{*}{$\mathrm{Zn}(\mathrm{II})+\mathrm{Cd}(\mathrm{II})+\mathrm{Hg}(\mathrm{II})$} & $\mathrm{Zn}(\mathrm{II})$ & 3.124 & 0.076 & 0.975 & 0.509 & 0.389 & 0.983 \\
\hline & $\mathrm{Cd}(\mathrm{II})$ & 2.130 & 0.070 & 0.994 & 0.343 & 0.397 & 0.968 \\
\hline & $\mathrm{Hg}(\mathrm{II})$ & 2.220 & 0.034 & 0.967 & 0.168 & 0.512 & 0.995 \\
\hline
\end{tabular}

Table 3: Modeling the results of adsorption isotherm of binary and tertiary components system.

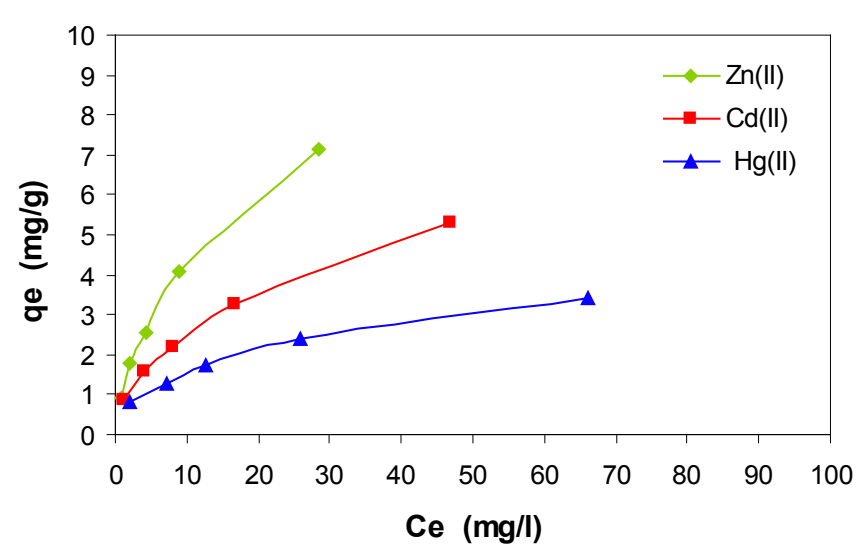

Figure 2: Isotherm curves for zinc (II), cadmium (II) and mercury (II) in monocomponent system using rice husk ash.

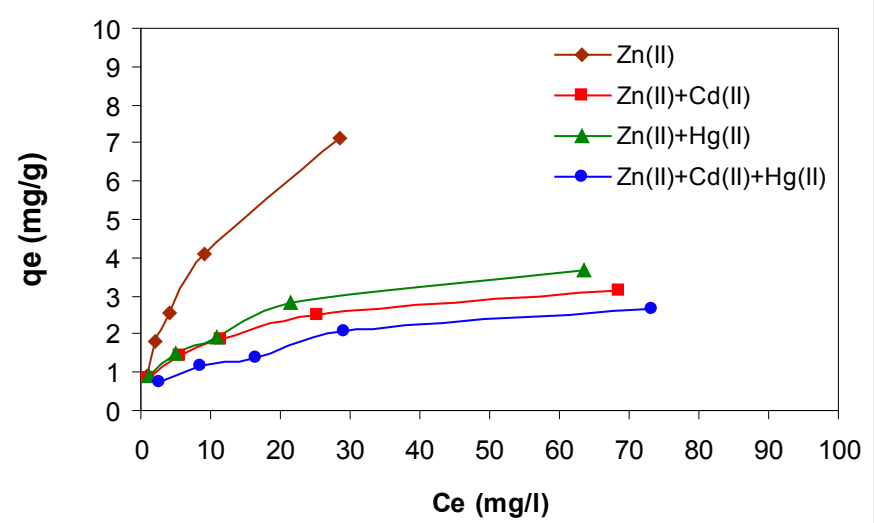

Figure 3: Zinc(II) adsorption onto rice husk ash in binary and tertiary system with cadmium(II) and mercury (II).

to each metal ions were analyzed with well known adsorption models such as Langmuir and Freundlich.

Langmuir model: The Langmuir isotherm is a commonly applied model for adsorption on a completely homogeneous surface with negligible interaction between adsorbed molecules. The model assumes uniform adsorption energies onto the surface and maximum adsorption depends on saturation level of monolayer [13].

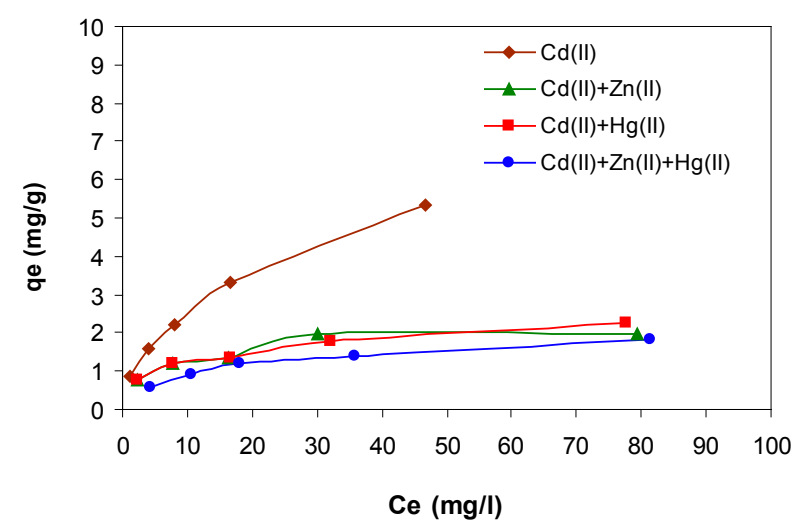

Figure 4: Cadmium(II) adsorption onto rice husk ash in binary and tertiary system with zinc(II) and mercury (II).

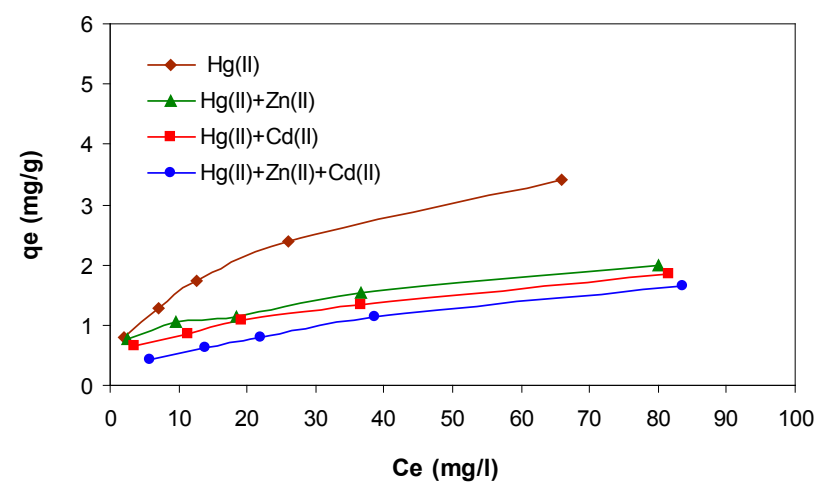

Figure 5: Mercury (II) adsorption onto rice husk ash in binary and tertiary system with zinc(II) and cadmium (II).

Langmuir mode can be represented with the following linear equation.

$$
\frac{\mathrm{C}_{\mathrm{e}}}{\mathrm{q}_{\mathrm{e}}}=\frac{1}{\mathrm{Q}_{\mathrm{o}} \mathrm{b}}+\frac{\mathrm{C}_{\mathrm{e}}}{\mathrm{Q}_{\mathrm{o}}}
$$

Where $\mathrm{q}_{\mathrm{e}}$ represents the mass of adsorbed metal ion per unit resin $(\mathrm{mg} / \mathrm{g}), \mathrm{Q}_{\mathrm{o}} \mathrm{mg} / \mathrm{g}$ is the mono layer capacity, $\mathrm{b}(1 / \mathrm{mg})$ is the equilibrium constant and $\mathrm{Ce}$ is the equilibrium concentration of the solution $(\mathrm{mg} / \mathrm{l}), \mathrm{Q}$, and $\mathrm{b}$ are langmium constant related to adsorption capacity and energy of adsorption, respectively. The essential characteristics of 
Citation: El-Said AG, Badawy NA, Garamon SE (2018) Adsorption of Heavy Metal lons from Aqueous Solutions onto Rice Husk Ash Low Cost Adsorbent J Environ Anal Toxicol 7: 543. doi: 10.4172/2161-0525.1000543

Page 4 of 5

a Langmuir isotherm generally expressed in terms of dimensionless constant called equilibrium parameters $\mathrm{R}_{\mathrm{L}}$, which is defined as by [14]:

$$
\mathrm{R}_{\mathrm{L}}=\frac{1}{1+\mathrm{bCo}}
$$

Where $\mathrm{b}$ is defined as Langmuir constant $1(\mathrm{mg})$ and Co as initial concentration (mg/l). $R_{L}$ values were calculated using Eq. (3) for $\mathrm{Zn}$ (II), Cd (II) and $\mathrm{Hg}$ (II) ions. The value was found to be between 0 and 1 at different initial concentrations indicating favorable adsorption of all three metal ions in mono component system.

Freundlich model: The Freundlich model is known as earliest empirical equation and is shown to be consistent with exponential distribution of active centers, characteristic of heterogeneous surface $[15,16]$.

$$
\log \mathrm{q}_{\mathrm{e}}=\log \mathrm{K}_{\mathrm{f}}+\frac{1}{\mathrm{n}} \log \mathrm{C}_{\mathrm{e}}
$$

Where $\mathrm{K}_{\mathrm{ef}}$ and $\mathrm{n}$ represent adsorption capacity and intensity, respectively, $\mathrm{K}_{\mathrm{ef}}$ is an important constant used as relative measure for adsorption efficiency. The magnitude of the $\mathrm{n}$ shows an indication of the favorability of adsorption. Values of $\mathrm{n}$ larger than 1 show the favorable mature of adsorption [17] (Figure 2). For the mono component isotherms when concentration is expressed in $\mathrm{mg} / \mathrm{l}$, the adsorption capacities in $\mathrm{mg} / \mathrm{g}$ increase in the following order $\mathrm{Zn}$ (II) $>\mathrm{Cd}$ (II) $>\mathrm{Hg}$ (II) ions. Maximum adsorption capacity, $\mathrm{Q}_{\mathrm{o}}(\mathrm{mg} / \mathrm{g})$ calculated from Langmiur isotherm and Freundlich parameter $\mathrm{K}_{\mathrm{f}}$ as presented in Table 2 , are in increasing order $\mathrm{Zn}(\mathrm{II})>\mathrm{Cd}(\mathrm{II})>\mathrm{Hg}(\mathrm{II})$, isotherm curves shown in Figure 2. Determination coefficient, $\mathrm{r}^{2}$ of both, Langmuir and Freundlich equations, is near to unity, indicating the good agreement of experimental data with both the isotherm models in case of monocomponent system.

\section{Adsorption of metal ions in binary and tertiary system}

Binary adsorption studies are particularly important for assessing the degree of interference posed by common metal ions in adsorptive treatment of waste waters. The binary system adsorption isotherms for metal ion $\mathrm{Zn}$ (II), Cd (II) and Hg (II) have been given in Figures $3-5$, respectively. As depicted in the figures, for each metal ion, coadsorption induces a decrease in equilibrium adsorption capacity, but the percentage of decrease depends on co-metal ion present in the system. Adsorption behaviors of the metal ions in binary system have been modeled using Langmuir and Freundlich equation as presented in Table 3. Previous studies have explained the removal of metal ion in adsorption competitive system on the basis of comparative assessment of their initial adsorption rates $[18,19]$.

Langmuir equation was also applied with respective monocomponent isotherm in presence of other metal ions for a binary and tertiary system. Figures 3-5 presents isotherms curves obtained for Coadsorption of $\mathrm{Hg}$ (II), Zn (II) and Cd (II) in tertiary system of Zn (II) + $\mathrm{Cd}$ (II) and $\mathrm{Hg}$ (II). It can be easily observed that sorption is decreased in the presence of other bivalent metal ions. This is due to screening effect of surface charged produce by the added metal ions [20,21]. For analysis of the $k_{f}$ of the values from Frendlich isotherm equation is revealed is that the order of adsorption was $\mathrm{Zn}$ (II) $>\mathrm{Cd}$ (II) $\mathrm{Hg}$ (II). The differentiated behavior of adsorption of $\mathrm{Hg}$ (II) can be explained by the strong interference of the size of the particle of the material adsorbent used on the process of adsorption as it can be observed by the data of the literature $[22,23]$. The lower adsorption value observed for $\mathrm{Hg}$ (II) it can also be presumably due to the stronger interaction of $\mathrm{Hg}$ (II) with $\mathrm{Cl}^{-}$species in solution phase, $\mathrm{Hg}$ (II) can form stable species such as $\mathrm{HgCl}^{+}$and $\mathrm{HgCl}_{2}$ in solution phase while for $\mathrm{Zn}$ (II) and Cd (II) this interaction is negligible. It is also clear that the amount of adsorbed $\mathrm{Zn}$ (II) is larger than that of Cd (II). This may be due to the smaller ionic size of Zn (II) (0.74 ̊̊) than the Cd (II) (0.83 ̊́), reported higher sorption of $\mathrm{Zn}$ (II) than that Cd (II) on to peat [20].

\section{Conclusions}

The equilibrium sorption of three metal ions-Zn (II), Cd (II) and $\mathrm{Hg}$ (II) on rice husk ash (RHA) has been studied for three, mono, binary and ternary component systems... Studies on equilibrium quantitative sorption in mono-component, and binary system have revealed that competition has occurred. The results show that, the perfectly adsorption of the following metals in the order of $\mathrm{Zn}$ (II) $>\mathrm{Cd}$ (II) $>\mathrm{Hg}$ (II) in a single system. In the binary and tertiary systems, the sorption is suppressed by the presence of other metal ions in aqueous solution. The equilibrium data have been analyzed, for each metal ion in each system using Langmuir and Freundlish models can be used to fit the data and estimate model but certainly not in all the cases of adsorbent and adsorbate system. The results indicate that it is important to understand the mechanisms of competitive adsorption of coexisting metals onto RHA biosorbent for the effective operation of adsorption processes for the removal of heavy metals in waste water or polluted water.

\section{References}

1. Rozada F, Otero M, Morán A, García Al (2008) Adsorption of heavy metals onto sewage sludge-derived materials. Bioresource Technology 99: 6332-6338.

2. Otero M, Rozada F, Morán A, Calvo LF, García Al (2009) Removal of heavy metals from aqueous solution by sewage sludge based sorbents: competitive effects. Desalination 239: 46-57.

3. Bhatnagar A, Minocha AK, Sillanpää M (2010) Adsorptive removal of cobalt from aqueous solution by utilizing lemon peel as biosorbent. Biochemical Engineering Journal 48: 181-186.

4. Naiya TK, Bhattacharya AK, Mandal S, Das SK (2009) The sorption of lead (II) ions on rice husk ash. Journal of hazardous materials 163: 1254-1264.

5. Srivastava VC, Mall ID, Mishra IM (2008) Removal of cadmium (II) and zinc (II) metal ions from binary aqueous solution by rice husk ash. Colloids and surfaces A: physicochemical and engineering aspects 312: 172-184.

6. Ghaedi M, Reza Fathi M, Shokrollahi A, Shajarat F (2006) Highly selective and sensitive preconcentration of mercury ion and determination by cold vapor atomic absorption spectroscopy. Analytical Letters 39: 1171-1185.

7. Shokrollahi A, Ghaedi M, Shamsipur M (2009) Highly selective transport of mercury (II) ion through a bulk liquid membrane. Química Nova 32: 153-157.

8. Manohar DM, Krishnan KA, Anirudhan TS (2002) Removal of mercury (II) from aqueous solutions and chlor-alkali industry wastewater using 2-mercaptobenzimidazole-clay. Water Research 36: 1609-1619.

9. Tuzen M, Sari A, Mendil D, Soylak M (2009) Biosorptive removal of mercury (II) from aqueous solution using lichen (Xanthoparmelia conspersa) biomass: kinetic and equilibrium studies. Journal of Hazardous Materials 169: 263-270.

10. Şengil IA, Özacar M (2008) Biosorption of Cu (II) from aqueous solutions by mimosa tannin gel. Journal of Hazardous Materials 157: 277-285.

11. Özacar M, Şengil IA, Türkmenler $H$ (2008) Equilibrium and kinetic data and adsorption mechanism for adsorption of lead onto valonia tannin resin. Chemical Engineering Journal 143: 32-42.

12. Li Q, Wu S, Liu G, Liao X, Deng X, et al. (2004) Simultaneous biosorption of cadmium (II) and lead (II) ions by pretreated biomass of Phanerochaete chrysosporium. Separation and Purification Technology 34: 135-142.

13. Langmuir I (1918) The adsorption of gases on plane surfaces of glass, mica and platinum. Journal of the American Chemical society 40: 1361-1403.

14. Parab H, Joshi S, Shenoy N, Lali A, Sarma US, et al. (2006) Determination of kinetic and equilibrium parameters of the batch adsorption of $\mathrm{Co}$ (II), $\mathrm{Cr}$ (III) and $\mathrm{Ni}$ (II) onto coir pith. Process Biochemistry 41: 609-615. 
Citation: El-Said AG, Badawy NA, Garamon SE (2018) Adsorption of Heavy Metal lons from Aqueous Solutions onto Rice Husk Ash Low Cost Adsorbent J Environ Anal Toxicol 7: 543. doi: 10.4172/2161-0525.1000543

Page 5 of 5

15. Ho YS (2005) Effect of $\mathrm{pH}$ on lead removal from water using tree fern as the sorbent. Bioresource Technology 96: 1292-1296.

16. Veliev EV, Öztürk T, Veli S, Fatullayev AG (2006) Application of Diffusion Model for Adsorption of Azo Reactive Dye on Pumice. Polish Journal of Environmental Studies p: 15.

17. Daneshvar N, Salari D, Aber S (2002) Chromium adsorption and Cr (VI) reduction to trivalent chromium in aqueous solutions by soya cake. Journal of Hazardous Materials 94: 49-61.

18. Ho YS, Wase DJ, Forster CF (1996) Kinetic studies of competitive heavy metal adsorption by sphagnum moss peat. Environmental Technology 17: 71-77.

19. Ho YS, McKay G (1999) Competitive sorption of copper and nickel ions from aqueous solution using peat. Adsorption 5: 409-417.
20. Ma W, Tobin JM (2003) Development of multimetal binding model and application to binary metal biosorption onto peat biomass. Water Research 37 3967-3977.

21. Petrus R, Warchoł JK (2005) Heavy metal removal by clinoptilolite. An equilibrium study in multi-component systems. Water Research 39: 819-830.

22. Tiwari DP, Singh DK, Saksena DN (1995) Hg (II) adsorption from aqueous solutions using rice-husk ash. Journal of Environmental Engineering 121: 479-481.

23. Chuah TG, Jumasiah A, Azni I, Katayon S, Thomas SY (2005) Choosing Rice busk a potentially low-cost biosorbent for hevy metal and dye removal: an overview. Desalination 175: 305-316. 